\title{
The Mediating Effect of Job Satisfaction on the Relationship of HR Practices and Employee Job Performance: Empirical Evidence from Higher Education Sector
}

\author{
Muhammad Asad khan $^{1 *}$, Rosman Md Yusoff ${ }^{2}$, Altaf Hussain ${ }^{1}$, Fadillah Binti Ismail ${ }^{1}$ \\ ${ }^{1}$ Faculty of Technology Management and Business, Universiti Tun Hussein Onn Malaysia \\ ${ }^{2}$ Faculty of Applied Science and Technology, Universiti Tun Hussein Onn Malaysia
}

Keywords:
HR practices,
Employee job performance,
Faculty members,
Higher education sector,
Empirical study

Received
26 Sep 2018
Received in revised form
18 December 2018
Accepted
18 December 2018

Correspondence:

Asadkhan818@yahoo.com

\begin{abstract}
The aim of this research is to analyze the effect of human resource practices (HR) on employee job performance under the mediating effect of job satisfaction. A total of 300 faculty members from six public sector universities responded to the self-administered questionnaire. The findings come from both descriptive statistics and inferential statistics using cross-sectional data which was performed at the expediency of the scholar. Confirmatory factor analysis (CFA) was performed using structural equational modelling (SEM) to obtain the results of the study. This study has found that HR practices: recruitment and selection, training and development, performance appraisal and compensation have direct and significant effect on employee job performance through job satisfaction among the university faculty members. The impact of these HR practices has widely been studied and their importance has acknowledged. However, the number of studies addressing this issue in public-sector universities is extremely scarce. This study has addressed that gap. The findings of the study, if given serious note by the policy makers in the respective field, are expected to improve employee job performance. The study is expected to have enriched the body of knowledge on the mediating effect of job satisfaction on the relationship of HR practices and employee job performance in the target population and has validated past findings.
\end{abstract}

C AIMI Journals

Human resource (HR) is considered to be significant and critical area of management including HR practices in the western world for the last few years. The effect of HR practices on performance and job satisfaction is attracting a considerable attention globally since the past 25 
years (Mohammad, Miah, Rahman, \& Rahaman, 2017). Organizations which are serious about these HR practices are implemented; their employees feel secure and comfortable which, in return, enhance the level of employee job performance in a better way (Nadarajah, Kadiresan, Kumar, Kamil, \& Yusoff, 2012; Saleem \& Khurshid, 2014). HR practices like recruitment and selection, performance appraisal, training and development and compensation implemented in organizations have been linked with almost all managerial functions and implementation of these HR practices help maximize the competences of employees in the organization (Saleem $\&$ Khurshid, 2014). Every organization knows the values of employees because they contribute in their growth and success (Amin, Khairuzzaman Wan Ismail, Zaleha Abdul Rasid, \& Daverson Andrew Selemani, 2014; Singh \& Kassa, 2016). Organizations are required to acknowledge their importance to retain its employees in accordance with rapid and continuous change globally and also ensure knowledge capital to be productive and reactive to the requirements of their stakeholders (Malik, Nawab, Naeem, \& Danish, 2010; Singh \& Kassa, 2016).

Previous studies have identified that effective application of some imperative human resource practices will enable both employee and organizational performance (Vermeeren, Steijn, Tummers, Lankhaar, Poerstamper, \& van Beek, 2014). These practices have also positive impact on employee job performance (Ahmad \& Shahzad, 2011; Hassan, 2016). Amin et al. (2014) noticed that employee's role is strategic in the enhancement of overall rating of universities. Their role is strategic in key areas such as research quality, faculty academic reputation, contribution to society in terms of research and preparation of leaders for future. Organizations need employees with diverse skills that enable them to cope with organizational problems (Amin et al., 2014). High ranking learning institutions are expected to produce human resources of high quality and caliber (Singh \& Kassa, 2016). The effectiveness of qualified human resources is totally dependent on the execution of effective HR practices such as recruitment and selection, training and development, performance appraisal and compensation.

Notwithstanding, the realization of these facts are still demand empirical evidences to lend more support to it. No doubt, the importance of HR practices has been studied in various countries and organizations. Researchers (Amin et al., 2014; Singh \& Kassa, 2016) are not content with the amount of empirical evidences carried out so far in public universities. Previous literature has recognized that HR practices play a key role in affecting the employee job performance (Hassan, 2016; Shahzad, Bashir, \& Ramay, 2008). But in developing countries like Pakistan the studies on the role of HR practices are limited and also their impact on employee job performance is not adequately addressed (Zia-ur-Rehman, Faisal, \& Khan, 2015). In most of the African countries such as Nigeria it was recognized that most of the HR professionals used these HR practices like training and development, performance appraisal and recruitment and selection and attained some fruitful results (Ahmad \& Shahzad, 2011). The reason for choosing these variables is that because less study has been conducted on the surface regarding the impact of HR practices on employee job performance in developing countries like Pakistan and particularly about its physiological needs, i.e., recruitment and selection, performance appraisal, compensation and training and development (Hashim, Rafi, Kazmi, Ullah, \& Kee, 2017). 
Faculty members should also depend on getting social status which can be fulfilled by applying these practices in a fair way. Bashir and Khattak (2008) argued that industries and organizations pursuing long term incentive plans to achieve more return on equity rather than those who disregard such plans. Tessema and Soeters (2006) have also proposed that there is positive relationship between compensation practices and employee job performance. Strong evidence shows in past literature that different HR practices have a deep impact on employee job performance and various researchers also found positive relationship between recruitment and selection and performance (Delaney \& Huselid, 1996), training and development (Huselid, 1995), compensation and performance appraisal and job performance (Bilal \& Naintara, 2011). This study will give empirical evidence about the effect of selected HR practices (recruitment and selection, training and development, performance appraisal and compensation packages) on employee job performance. No earlier work could be found that pointing the HR issues under consideration in public sector universities of Pakistan. The findings of this study will assist higher education sector in general and public-sector universities of Pakistan in particular in answering the long-standing question of how to improve employees' job performance.

\section{Rationale for Research}

In general, Pakistan is considered to be under researched country in terms of HR practices (Hashim et al., 2017; Rehman, 2012). A noticeable gap has been found in the complex situation of the HR practices exist in both public and private sector in Pakistan especially regarding HR practices and reflects a very gray picture of HR practices and its impact on employee job performance (Zia-ur-Rehman et al., 2015). In Pakistan, literacy rate is very nominal while public-sector is the major education providing sector and it is assumed that beside other factors faculty members' performance and satisfaction is perceived a major problem for low literacy (Hashim et al., 2017). Higher education role is crucial in the socioeconomic development of a nation and universities are the sanctuaries of high quality graduates. It is important that universities should identify and retain experience and capable academic staff. This could only be affected with the help of sound HR practices. Till now, there are only four public sector university of Pakistan ranked among top universities of the world (Raza, 2017, September 05) which is an insignificant number.

\section{Literature Review and Hypotheses Development HR Practices and Employee Job Performance}

Human resource management is gaining momentum in contributing towards organizational performance in the current years worldwide, particularly in the perspective of public sector organizations (Rehman, 2012). To survive in the current globalized world, it has become imperative for organization to formulate viable policies and practices to maximize employee job performance (Akinbode, 2011) and without that it is hard to enhance productivity of the organization and maximize its employee's efficiency in a unique way (Zia-ur-Rehman et al., 2015). This is the only way for gaining competitive edge (Bilal \& Naintara, 2011). Employee job performance refers to those behaviors which can be scaled and measured and are performed within the workplace and subject to the outcomes of their activities and work (Ahmad \& Shahzad, 2011). Employee job performance can be taken in the perspective of those factors, 
i.e., HR practices which have direct impact on such relationship. Historically, human resource management practices (recruitment and selection, training and development, performance evaluation, rewards, and compensation) have been tested and adopted for getting competitive advantage in the western world but nevertheless in Pakistan (Ahmad \& Shahzad, 2011). Generally, past empirical research results are not conclusive about the relationship of HR practices and employee job performance. For example, for Khilji (2002) there exist negative relationship, for Wright and Kehoe (2008) there exist weak relationship while researchers that advocate the existing of relationship are greater in number (Ali \& Jadoon, 2012; Vermeeren et al., 2014; Petros, 2014; Zia-ur-Rehman et al., 2015). Notwithstanding, employees job performance is considered vital factor in success of organizations, however, limited studies investigated the direct effect of HR practices on employees' job performance (Quresh, Akbar, Khan, Sheikh, \& Hijazi, 2010).

Research scholars classify HR practices as recruitment and selection, job definition, performance appraisal, compensation, employee participation and training and development and postulate that implementation of these HR practices in true sense will not only increase employee satisfaction and commitment but also result in increase of both individual and organizational performance (Khan, 2010; Quresh et al., 2010). Similarly, researchers (Abdullah, Ahsan, \& Alam, 2009; Amin et al., 2014) opine that HR practices such as training and development; HR planning and performance appraisal has positive effect on both individual and organization. These studies have been carried out in different organizational settings like high tech industrial park, banking sector and universities, etc. Researchers (Nadarajah et al., 2012; Sattar, Ahmad, \& Hassan, 2015; Shah et al., 2012) have found that HR practices like recruitment and selection, compensation, performance appraisal and training and development have significant and positive effect on both employee job performance and productivity. On the basis of above mentioned literature we propose the validation of the following hypothesis in the target population:

$\mathbf{H}_{1}$ : HR practices are significantly and positively related to employee job performance.

\section{Recruitment and Selection and Employee Job Performance}

Recruitment is known as a procedure used by organizations to attract and place individuals in order to fill the job vacancies. It can also be delineated as identification and attraction of potential candidates by the organization (Amin et al., 2014). While, selection is a process which decreases the pool of candidates and the selection of suitable candidate is made from the pool based on the relevant qualification and predefined criteria. Right selection of candidates should be made based on appropriate evaluation and selection as inappropriate assessment and selection will lead the organization towards failure in accomplishment of its goals and also accompany range of issues like high turnover, low productivity, employee stress and dissatisfaction (Storey, 2007). In order to increase the competitive advantage, efficiency and effectiveness, organization should select the best recruitment and selection process which help the organization in creation of best group of candidates. According to Rehman (2012), recruitment and selection is one of the best HR practices that help managers of the organizations in selection and attraction of potential candidates which, in turn, leads to both 
enhanced job performance and organizational performance. Many scholars agreed on this point that effective recruitment and selection process leads to both competitive advantage and high job performance of employees (Amin et al., 2014). Several scholars opined that recruitment and selection is significantly and positively related to employee job performance (Alsabbah \& Ibrahim, 2014; Khan, 2012). On the basis of above mentioned literature we propose the validation of the following hypothesis in the target population:

$\mathbf{H}_{2}$ : Recruitment and selection is significantly and positively related to employee job performance.

\section{Training and Development and Employee Job Performance}

Training and development is used as an important tool which provides employees with the knowledge, skills and abilities and also modifies their behaviors and attitudes to perform efficiently both in the present and future (Ahmed \& Yohanna, 2014). It helps in increasing the performance of employees both at individual and organizational level (Al-Mzary, Al-rifai, \& Al-Momany, 2015; Okechukwu, 2017). It is highly critical for every organization as it meant to modify not only skills, attitudes and behaviors of employees but also make them adapt to new technology which in turn increases the efficiency of both individual and organization (Khan, Abbasi, Waseem, Ayaz, \& Ijaz, 2016). Researchers (Afsana, Afrin, \& Tarannum, 2016; Singh, 2016) have found positive relationship between training and development and employees job performance. Anyhow, most of these studies have been conducted in industrial organizational settings (Khan et al., 2016; Tahir, Yousafzai, Jan, \& Hashim, 2014) while less attention has been given to such relationship in higher education sector (Al-Mzary et al., 2015). Therefore, we feel that there is a need of validation of the above findings in the target population. Hence, the following hypothesis:

H3: Training and development is significantly and positively related to employee job performance.

\section{Performance Appraisal and Employee Job Performance}

Performance appraisal is the method of identifying and improving employees' job performance and aligning employees' job performance with organizational goals and objectives (Amin et al., 2014). The purpose of performance appraisal is to evaluate the employee job performance and help them in improving their productivity level and subsequently individual and organizational performance (Dar, Bashir, Ghazanfar, \& Abrar, 2014). The basic aim of performance appraisal is improving individual performance with the prescribed standards, i.e., enhancement of present performance, development of motivation and identification of training and development, and it is positively correlated with employee's job performance (Abutayeh \& Al-Qatawneh, 2012). According to Dar et al. (2014), fair performance appraisal improves employee's job performance and sequentially positively influences organizational performance. While, Amin et al. (2014) postulated that ineffective performance appraisal could have negative impact on employee's morale and produces frustration and dissatisfaction among employees. Brown and Heywood (2005) suggested that complementary human resource 
management practices such as training and development, compensation practices and performance appraisal lead to greater influence on employee's productivity. Literature reveals that performance appraisal has a significant positive relationship with employee's job performance (Ahmad \& Shahzad, 2011; Khan, 2010; Khan, Khan, \& Khan, 2017).

On the basis of above mentioned literature we propose the validation of the following hypothesis in the target population:

H4: Performance appraisal is significantly and positively related to employee job performance.

\section{Compensation Practices and Employee Job Performance}

Compensation is the reward given by organization to their employees in return for exhibiting willingness to perform various jobs and services in the organization (Rana \& Malik, 2017). According to Sardar, Rehman, Yousaf, and Aijaz (2011), compensation can be both financial and non-financial rewards; financial rewards comprises of pay, bonuses and non-financial rewards involves extra holidays and other recreational schemes. In order to achieve high job performance within organization, it is crucial to engage employees with smart compensation packages (Rana \& Malik, 2017). A fair and just compensation package confirms high morale subsequently high employees' job performance and is considered a robust contributor towards employee job performance. According to the view of Ahmad and Shahzad (2011), performance is directly related to financial rewards. Bashir and Khattak (2008) argued that those industries and organization achieve more return on equity pursuing long term incentives against those organizations who disregards such incentive plans. Tessema and Soeters (2006) also found positive relationship between compensation practices and employees job performance and these findings have been validated in other settings by other researchers (Bashir \& Khattak, 2008; Nzyoka \& Orwa, 2016).

On the basis of above mentioned literature we propose the validation of the following hypothesis in the target population:

H5: Compensation practices are significantly and positively related to employee job performance.

\section{HR Practices and Job Satisfaction}

The effect of HR practices on performance and job satisfaction have attracted much attention globally over the previous 25 years (Mohammad et al., 2017). According to Pradhan, Dash, and Jena (2017), HR practices perform an influential role in increasing the efficiency of employee job performance to achieve organizational goals and objectives. Previous debates regarding HR practices outcomes specify that HR practices of the organization backed the employees to improve their confidence, motivation and satisfaction which in turn make them more energetic, committed and gripped in their jobs (Pradhan et al., 2017). In the same line, Khan (2010) postulated that a developed and pre-defined approach of HR practices is inevitable to be implemented in an organization for achieving high job satisfaction and subsequently high job performance. 
Job satisfaction can be termed as the emotional feeling of one' job experience or evaluation of an individual work. Satisfaction is primarily employee's thinking of their own jobs (Locke, 1976). It is a significant indicator for establishing employee's feelings towards their jobs and the level of satisfaction with their consequent jobs. Organizations have started paying more attention on making employees satisfied with their jobs by implementing different HR practices. Gürbüz (2009) proposed that for sustainable position in this highly competitive business global era, organization needs to adopt adequate HR practices which enhance job satisfaction of employees and bear several important advantages for the organization. Previous researchers have described about the positive relationship between HR practices and job satisfaction (Pradhan \& Jena, 2016). Several researchers advocated the impact of HR practices on organizational performance through the employees' behavior and attitude such as job satisfaction, motivation and commitment (Byremo, 2015; Guest, 1997). HR practices affect employees' behavior based on social exchange theory (Michael, 1964) and signaling theory (Casper \& Harris, 2008).

On the basis of above mentioned literature we propose the validation of the following hypothesis in the target population:

H6: Job satisfaction is significantly mediated the relationship between HR practices and employee job performance.

\section{Mediating Role of Job Satisfaction}

Previously, researchers' have identified the direct relationship of HR practices and job satisfaction or HR practices and employee job performance (Mohammad et al., 2017). This study proposes that if the HR practices, i.e., recruitment and selection, performance appraisal, training and development and compensation implemented in the universities are effective, fair, unbiased, sufficient and ample, faculty members will be satisfied and, in return, their performance will be enhanced. However, in this study job satisfaction will be used as a mediator to investigate its mediating effect. In this study the researcher will assimilate both the subjects in a single edge to explore empirically as to what extent it mediates the relationship in the target population.

\section{Theoretical Foundation}

This study is theoretically supported by social exchange theory (Michael, 1964) and signaling theory (Spence, 1974). Social exchange theory is based on two types of resources, i.e., economic and social resources. This study relates with social aspect of social exchange theory which is based on love, respect and support while the economic aspect of this theory is based on money and material. This theory corroborates that employees are in exchange relationship with organization and pay back in kind what they receive from an organization (Conway \& Briner, 2005). This theory further postulates that maximum organizational support via HR practices will make the employees gratified towards their concerned organization (Shore \& Wayne, 1993) and, in return, employees will try to respond it through efficient job performance. 
On the other hand, signaling theory relates to the description of the two behaviors, that is, individual and organization. It elaborates that one party acts as a sender of the signal (information) and simultaneously strives how to send signal while the other acts as a receiver and strives how to interpret the signal (Connelly, Certo, Ireland, \& Reutzel, 2010). This theory is used as supporting in the sense that if the organization signals the HR practices in the way that employees interpret them as fair, just, right and according to their needs in response they interpret the signal of the organization and exhibit satisfaction, gratification and maximum job performance. This theory has suggested that the impact of HR practices on the employees' behaviors are acting as 'signals' carrying the organizational motive for the employees and in return the employees will try to respond it through efficient and high job performance.

\section{Conceptual Framework}

The conceptual framework for this study is represented diagrammatically based on the relationships of constructs of study and their order of influence (Figure 1). The first flow of influence in this framework is initiated from direct relationship of HR practices, i.e., recruitment and selection, training and development, performance appraisal and compensation with employee job performance. The second flow in the conceptual framework is initiated relating HR practices with job satisfaction. While, the third flow of influence in the framework is of HR practices on employee job performance through a mediator of job satisfaction. This broad framework of the study proposes hypotheses for testing based on the relationship of constructs included in the study. In summary, this conceptual framework proposes three main relationships, that is, a) direct and positive relationship of HR practices with employee job performance, b) direct and positive relationship of HR practices with job satisfaction, and c) the mediating effect of job satisfaction on the relationship of HR practices and employee job performance.

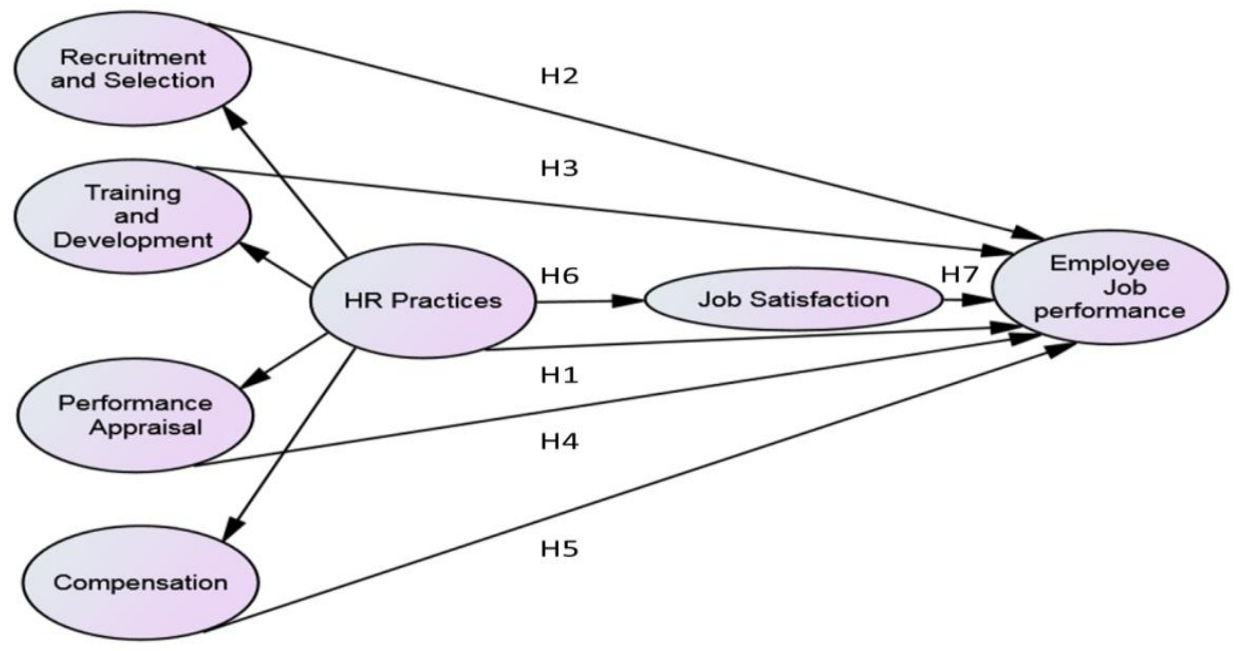

\section{Method}

Figure 1. Conceptual framework of the study

This research is a survey type research that used questionnaire for data collection. Data is quantitative and cross-sectional. Both descriptive and inferential statistical techniques were 
employed. Simple random sampling technique was employed. Data were collected from a total of 300 academic staff of six public sector universities of Khyber Pakhtunkhwa, Pakistan. Out of 300 questionnaires, 250 were returned back recording a response rate of $83 \%$. Out of 250 , ten questionnaires were omitted due to missing data for final analysis.

\section{Measures}

The survey instruments used in the study were adapted from previous studies (Quresh et al., 2010; Shahzad et al., 2008; Tsui, Egan, \& O'Reilly, 1992). The instrument consists of three parts: HR practices, job satisfaction and employee job performance.

HR practices: HR practices adopted scale from Quresh et al. (2010) and Shahzad, et al. (2008). It is five-point Likert scale ranging from $1=$ strongly disagree to $5=$ strongly agree. It has 20 items in total. Cronbach's alpha value of the scale is .82 .

Employee job performance: For measurement of this construct, the scale was adopted from Shahzad et al. (2008). It is five-point Likert scale ranging froml=strongly disagree to $5=$ strongly agree. It has 20 items in total. Cronbach's alpha value of the scale is .74.

Job satisfaction: The construct of job satisfaction was assessed using a scale adopted from Tsui et al. (1992). It is five-point Likert scale ranging from $1=$ strongly disagree to $5=$ strongly agree. It has 20 items in total. Cronbach's alpha value of the scale is .81 .

\section{Summary of Findings \\ Demographic Characteristics}

Demographics of the respondents include age, gender, marital status and qualification. The results revealed that the majority of the respondents happens to be male with $70 \%$ against $30 \%$ female. Regarding age of the respondent's age group of 30 to 36 years record $60 \%$ against age group of 25 to 30 years with $40 \%$. On qualification scale, MS/MPhil degrees holders are $50 \%$ while $30 \%$ respondents are $\mathrm{PhD}$ degree holders and the remaining respondents are master degree holders.

\section{Data Analysis}

For data analysis, Statistical Package for the Social Sciences (SPSS-23) and Analysis of Moment Structure (AMOS-23) has been employed. To analyze, the model structural equation modeling (SEM) has been employed. SEM is a statistical tool which permits the researcher to statistically find the existing relationships among different variables, i.e., multiple regression analysis simultaneously. SEM permits us to analyze the degree up to which job satisfaction acts as a mediator between HR practices and employee job performance. In addition, it also provides us different values that help in establishing the compatibility of the proposed model fitness with the dataset. SEM can be utilized for two significant things such as validation of measurement model and testing and fitting and modification of the structural model (Byrne, 2001). Measurement model has been validated through confirmatory factor analysis, while the other concept is achieved via path analysis with latent variables (Schumacker \& Lomax, 2015). The main purpose of applying SEM is to identify a statistically appropriate theoretical model which has both practical and theoretical implications (Schumacker \& Lomax, 2015). The 
goodness of fit indices was observed via absolute fit indices and incremental fit indices, respectively.

\section{Measurement Model}

Confirmatory factor analysis (CFA) was carried out to check the reliability and validity of the constructs. Table 1 demonstrates outputs of the analysis. Composite reliability (CR) estimations for all the variables of the study lie between .74 to .92 establishing sufficient reliability for all the constructs; as recommended value of composite reliability is .70 or above (Fornell \& Larcker, 1981). The construct validity of the model is established using convergent and discriminant validity. Convergent validity is determined using the AVE values of the constructs. As the AVE values for all the constructs are above .50 which is the recommended cut off value establishing sufficient convergent validity for the model.

Table 1

Factor Loadings, Composite Reliability and Average Variance Extracted

\begin{tabular}{|c|c|c|c|c|c|}
\hline Constructs & Items & $\begin{array}{l}\text { Factor } \\
\text { loadings }\end{array}$ & $\mathrm{R}^{2}$ & $\begin{array}{c}\text { CR } \\
\text { (Above 0.6) }\end{array}$ & $\begin{array}{c}\text { AVE } \\
\text { (Above 0.5) }\end{array}$ \\
\hline \multirow{4}{*}{ HR practices } & Recruitment and selection & .82 & .66 & \multirow{4}{*}{.82} & \multirow{4}{*}{.88} \\
\hline & Training and development & .90 & .88 & & \\
\hline & Performance appraisal & .92 & .90 & & \\
\hline & Compensation & .88 & .84 & & \\
\hline \multirow{5}{*}{$\begin{array}{l}\text { Recruitment } \\
\text { selection }\end{array}$} & RAS-1 & .82 & .35 & \multirow{5}{*}{.74} & \\
\hline & RAS -2 & .83 & .41 & & \multirow{4}{*}{.81} \\
\hline & RAS -3 & .81 & .50 & & \\
\hline & RAS -4 & .73 & .36 & & \\
\hline & RAS -5 & .87 & .55 & & \\
\hline \multirow{5}{*}{$\begin{array}{l}\text { Training } \\
\text { development }\end{array}$} & TAD-1 & .78 & .51 & \multirow{5}{*}{.88} & \multirow{5}{*}{.81} \\
\hline & TAD -2 & .85 & .66 & & \\
\hline & TAD -3 & .77 & .47 & & \\
\hline & TAD -4 & .79 & .49 & & \\
\hline & TAD -5 & .88 & .45 & & \\
\hline \multirow{5}{*}{ Performance appraisal } & PA-1 & .88 & .57 & \multirow{6}{*}{.87} & \multirow{6}{*}{.85} \\
\hline & PA -2 & .81 & .56 & & \\
\hline & PA -3 & .84 & .62 & & \\
\hline & $\mathrm{PA}-4$ & .86 & .39 & & \\
\hline & PA -5 & .89 & .57 & & \\
\hline \multirow{5}{*}{$\begin{array}{l}\text { Compensation } \\
\text { practices }\end{array}$} & $\mathrm{CP}-1$ & .82 & .48 & & \\
\hline & $\mathrm{CP}-2$ & .87 & .54 & \multirow{4}{*}{.92} & \multirow{4}{*}{.85} \\
\hline & $\mathrm{CP}-3$ & .88 & .65 & & \\
\hline & $\mathrm{CP}-4$ & .89 & .60 & & \\
\hline & CP -5 & .83 & .69 & & \\
\hline \multirow{5}{*}{ Job satisfaction } & JS- 1 & .82 & .55 & \multirow{5}{*}{.86} & \multirow{5}{*}{.85} \\
\hline & JS- 2 & .91 & .48 & & \\
\hline & JS- 3 & .85 & .54 & & \\
\hline & JS- 4 & .87 & .52 & & \\
\hline & JS- 5 & .80 & .37 & & \\
\hline \multirow{5}{*}{$\begin{array}{l}\text { Employee job } \\
\text { performance }\end{array}$} & EJP- 1 & .81 & .40 & \multirow{5}{*}{.84} & \multirow{5}{*}{.72} \\
\hline & EJP- 2 & .90 & .34 & & \\
\hline & EJP- 3 & .87 & .44 & & \\
\hline & EJP- 4 & .89 & .53 & & \\
\hline & EJP- 5 & .84 & .38 & & \\
\hline
\end{tabular}

Table 2 presents discriminant validity for the model. The findings given in Table 2 point out that the sq. root of AVE value for every construct at the diagonal is maximum than squared inter-construct correlations (SIC) of each construct in the model proposing maximum level of 
discriminant validity (Fornell \& Larcker, 1981). As a whole, outputs are within the acceptable levels for which conform the reliability and validity for all the constructs of the model.

Table 2

AVE and Squared Inter Construct Correlations

\begin{tabular}{lllllll}
\hline & RAS & TAD & PA & CP & JS & EJP \\
\hline Recruitment and selection & $\mathbf{. 9 0 1}$ & & & & & \\
Training and development & .523 & $\mathbf{. 9 0 2}$ & & & & \\
Performance appraisal & .488 & .412 & $\mathbf{. 9 2 5}$ & & & \\
Compensation practices & .261 & .377 & .342 & $\mathbf{. 9 2 6}$ & & \\
Job satisfaction & .341 & .425 & .392 & .364 & $\mathbf{. 9 2 1}$ & $\mathbf{. 8 5 2}$ \\
Employee job performance & .372 & .512 & .453 & .525 & .436 & $\mathbf{. 8 5 2}$ \\
\hline
\end{tabular}

\section{Structural Model}

SEM is aimed to test simultaneously the regression pathways and assessment of model for goodness of fit (Table 3 and Figure 2). Four fit-statistics have been employed to check model fitness from different angles. They are: ratio of chi-square to degree of freedom $(\chi 2 / \mathrm{df})$, goodness of fit index (GFI), root mean square error of approximation (RMSEA) and root mean square residual (RMR) from absolute fit indices to evaluate the goodness of fit for the model. The values for these indicators were $\chi 2 / \mathrm{df}=1.89$, GFI $=.91, \mathrm{RMSEA}=.03$, RMR $=.04$, respectively. From incremental fit indices, the researcher used three measures, i.e., normed fit index (NFI), comparative fit index (CFI) and Tucker Lewis index (TLI) to assess the goodness of fit for the model. The values for these indicators were NFI $=.90$, CFI $=.96$ and TLI $=.95$, respectively. The values for both the measures, i.e., absolute fit indices and incremental fit indices were within the recommended range and hence it is concluded that the model fit well statistically to the data. The proposed hypotheses were analyzed using t-value, regression coefficient (beta co-efficient) and significance level. The regression path is found to be statistically significant if the t-value (C.R) is above +- 1.96 at $5 \%$ level of significance. It was also predicted that almost all the relationships in the model would be positive and same was confirmed for all the said relationships after analysis.

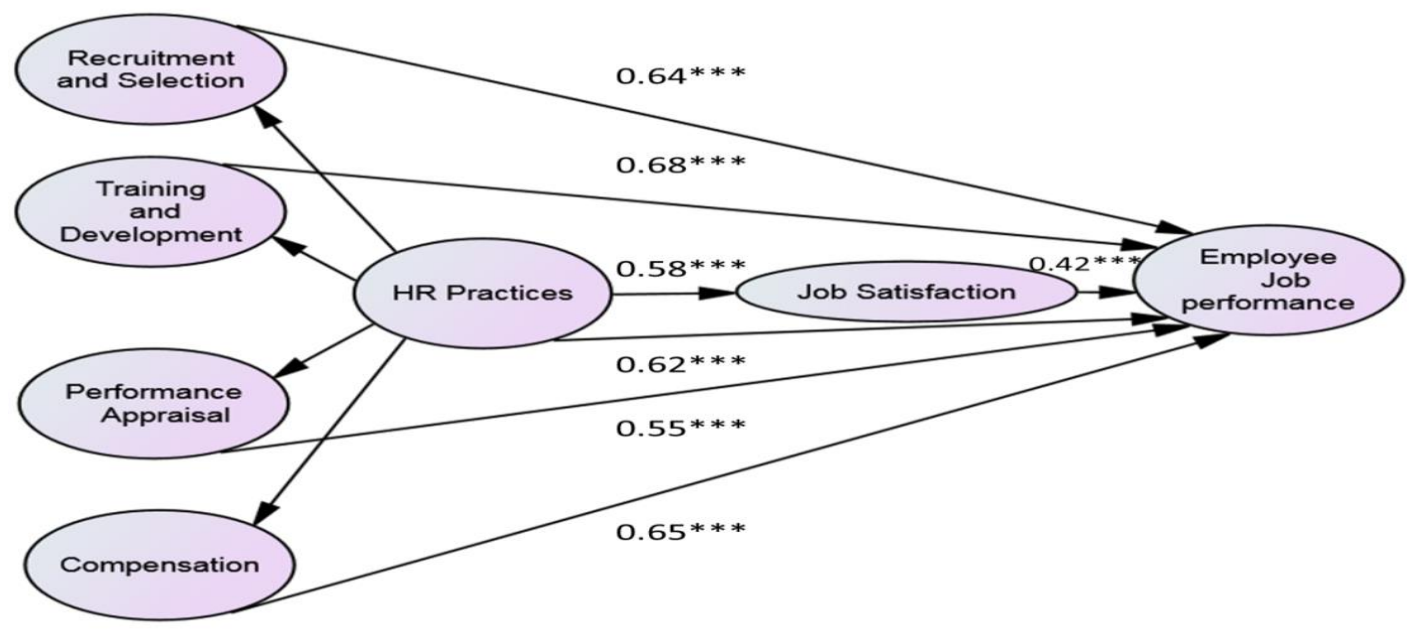

Figure 2. Structural model of study 
The squared multiple correlation (r2) shows the explanatory power of variance for each construct in the model. Overall, the model exhibited satisfactory and promising explanatory power for employee job performance by HR practices along with its dimensions. The variance caused by HR practices and its dimensions, i.e., recruitment and selection, training and development, performance appraisal and compensation were $42.5 \%, 58.4 \%, 44.3 \%$ and 49.6 $\%$, respectively.

Table 3

Model Fit Statistics

\begin{tabular}{ll}
\hline Chi -square (CMIN) & 1020.760 \\
\hline Degree of freedom (DF) & 54 \\
CMIN/DF & 1.89 \\
Goodness of fit index (GFI) & .91 \\
Root mean square error of approximation (RMSEA) & .03 \\
Root mean square residual (RMR) & .04 \\
Normed fit index (NFI) & .90 \\
Comparative fit index (CFI) & .96 \\
Tucker Lewis index (TLI) & .95 \\
\hline
\end{tabular}

\section{Results of Hypotheses Testing}

Six major hypotheses were proposed in the study to the test the relationship between the variables included in the study. The hypothesis formulated on the direct relationship of HR practices and employee job performance was found positive and statistically significant with path co-efficient $(\beta=.62, t=8.14, p<.05)$ supported and confirmed the first hypothesis. The path co-efficient for recruitment and selection $(\beta=.64, t=5.02, p<.05)$ was found positive and statistically significant and confirmed and supported the second hypothesis of the study. It was hypothesized in the study that training and development is significantly and positively related with employee job performance. The path co-efficient of training and development to employee job performance $(\beta=.68, t=-7.08 p<.05)$ was found positive and statistically significant and confirmed and supported the third hypothesis of the study. It was also hypothesized that performance appraisal is positively and significantly related to employee job performance. The path co-efficient of performance appraisal to employee job performance $(\beta=$ $.55, t=-9.02 p<.05)$ was found positive and statistically significant and validated and supported the fourth hypothesis of the study. Likewise, it was also hypothesized that compensation is positively and significantly related with employee job performance. The path co-efficient of compensation to employee job performance $(\beta=.65, t=8.28 p<.05)$ was found positive and statistically significant and confirmed and supported the fifth hypothesis of the study. Table 6 presents detailed results of all the proposed hypotheses.

\section{Mediating Effect of Job Satisfaction}

It was hypothesized in the study that job satisfaction has a mediating effect on the relationship of HR practices and employee job performance. Prior to test the mediating effect of job satisfaction, this study examined the direct effect of HR practices on employee job performance. The path co-efficient of HR practices to employee job performance $(\beta=.62, t=$ 
$8.14, p<.05$ ) was found statistically significant (Table 4). Job satisfaction is entered into the model as mediator. Then, the direct effect of HR practices on employee job performance is examined (Table 6). The direct effect of HR practices on employee job performance $(\beta=.31, t$ $=4.23, p>.05$ ) was found statistically insignificant and the magnitude of path co-efficient is reduced from .62 to .31 (Table 5). HR practices are also significantly and directly related to job satisfaction, i.e., path co-efficient of HR practices to job satisfaction is $(\beta=.58, t=6.24, p<$ .05 ) (Table 5). Job satisfaction is also directly and significantly related to employee job performance, i.e., path co-efficient of job satisfaction to employee job performance is $(\beta=.42, t$ $=9.21, p<.05)$ (Table 5). The mediation observed in the study is full mediation as path became insignificant and the magnitude of path co-efficient reduced from .61 to .31 after the entry of job satisfaction as a mediator in the model. In this case it is concluded that HR practices has a significant direct effect on employee job performance of academic staff through job satisfaction. The proposed hypothesis formulated in the study that job satisfaction significantly mediates the relationship of HR practices with employee job performance was supported and confirmed. All the proposed hypotheses formulated in the model to test relationships between variables were found statistically significant and confirmed. Table 6 presents detailed results of the proposed hypotheses of the study.

Table 4

The Direct Effect of HR Practices on Employee Job Performance

\begin{tabular}{|c|c|c|c|c|c|c|}
\hline Variable & Path & Variable & $\begin{array}{l}\text { Standardized } \\
\text { Estimate }\end{array}$ & CR/t-value & P-Value & Result \\
\hline EJP & $<---$ & HRP & .62 & 8.14 & .000 & Significant \\
\hline
\end{tabular}

Note. $\mathrm{HRP}=$ human resource practices, $\mathrm{JS}=$ job satisfaction $\mathrm{EJP}=$ employee job performance, $\mathrm{CR}=$ critical ratio

Table 5

Output of Job Satisfaction as a Mediator

\begin{tabular}{llllllll}
\hline Variable & Path & Variable & Standardized & Estimate & CR/t-value & P-Value & Result \\
\hline EJP & $<--$ & HRP & .31 & & 4.23 & .20 & Insignificant \\
JS & $<---$ & HRP & .58 & 6.24 & .000 & Significant \\
EJP & $<--$ & JS & .42 & 9.21 & .000 & Significant \\
\hline
\end{tabular}

Note. $\mathrm{HRP}=$ human resource practices, $\mathrm{JS}=$ job satisfaction $\mathrm{EJP}=$ employee job performance, $\mathrm{CR}=$ critical ratio

Table 6

Summary of the Findings of Hypotheses

\begin{tabular}{|c|c|c|c|c|}
\hline Hypotheses statement of path analysis & $\begin{array}{l}\text { Path } \\
\text { Co-efficietnt }\end{array}$ & $\begin{array}{l}\text { CR/t- } \\
\text { value }\end{array}$ & P-value & $\begin{array}{l}\text { Results on } \\
\text { Hypothesis }\end{array}$ \\
\hline $\begin{array}{l}\mathrm{H}_{1} \text { : HR practices is significantly and postively related with employee } \\
\text { job performance. }\end{array}$ & .62 & 8.14 & .001 & Supported \\
\hline $\begin{array}{l}\mathrm{H}_{2} \text { : Recruitment and selection is significantly and postively related } \\
\text { with employee job performance. }\end{array}$ & .64 & 5.02 & .001 & Supported \\
\hline $\begin{array}{l}\mathrm{H}_{3} \text { : Training and development is significantly and postively related } \\
\text { with employee job performance. }\end{array}$ & .68 & 7.08 & .002 & Supported \\
\hline $\begin{array}{l}\mathrm{H}_{4} \text { : Performance appraisal is significantly and postively related with } \\
\text { employee job performance. }\end{array}$ & .55 & 9.02 & .001 & Supported \\
\hline $\begin{array}{l}\mathrm{H}_{5} \text { : Compensation is significantly and postively related with employee } \\
\text { job performance. }\end{array}$ & .65 & 8.28 & .003 & Supported \\
\hline $\begin{array}{l}\mathrm{H}_{6} \text { : Job satisfaction is significantly mediated the relationship between } \\
\text { HR practices and employee job performnce. }\end{array}$ & .31 & 4.23 & .207 & Supported \\
\hline
\end{tabular}




\section{Discussion}

The current study empirically evaluates the relationship of HR practices with employee job performance through job satisfaction. All the measurement scales used in the study has been found valid and reliable based on composite reliability and construct validity, i.e., convergent and discriminant validity. After establishing the predicted relation among different constructs, the proposed model was analyzed through SEM to observe the model fitness on the basis of collected data. The proposed hypotheses which were projected to identify the structural association among the variables were analyzed. The proposed model is tested based on the goodness of fit statistics and is found fitted well to the data.

The primary objective of this study is to find the linkage between HR practices and employee job performance through job satisfaction. The findings of this study showed full mediation of job satisfaction between HR practices and employee job performance as hypothesized. The findings of this research are in line with the previous studies (Khan, 2010; Nadarajah et al., 2012; Quresh et al., 2010; Pangil, \& Othman, 2016; Sattar, Ahmad, \& Hassan, 2015) that HR practices have a positive impact on employee job performance and also match with the results of Steijn (2004) and Pradhan et al. (2017). Positive relationship of these two variables is due to the fact that HR practices of organization make employees obliged by investing in them. These variables have positive relationship because of the basic reason that organization employs effective HR practices to make them obliged via socio-economic resources by investing in them via HR practices. In respond, employees strive to reciprocate by being motivated, devoted and energetic and giving more focus to accomplish organizational goals and objectives (Macey \& Schneider, 2008). Extant literature links these relationships with social exchange theory and signaling theory. The findings of this study validate these contentions.

\section{Implications of the Study}

The results of the study have a number of practical and theoretical implications for academicians, scholars and practitioners. It gives deeper insights to HR managers and experts of public sector universities and other organizations to understand the interplay of these constructs with job performance. These results can help in devising effective HR practices to improve upon employee job performance through job satisfaction. There is enough stuff to instigate HR managers for designing good recruitment and selection process. The ample opportunities of training and development, fair and just performance appraisal and sufficient compensation will not only satisfy employees with their jobs but will also increase their level of job performance.

\section{Limitations}

The current study is not without limitations. First, the study employed a self-administered questionnaire which has an inherent subjectivity and biasness which affect the generalization of the research. Second, neither the list of independent variables is exhaustive nor the mediation is conclusive. Third, factors like considering only faculty members, sample size and representativeness, and the like have to be treated as limitations. Fourth and last, it is perception-based study and carries the limitations that human perception has. 


\section{Conclusion}

The study looked at the relationship of some HR practices and their impact on job performance with mediating role of job satisfaction. The results conclude significant relationship among the variables of study. The results purport that if public-sector universities have effective HR practices, employees will experience satisfaction with job and this will have positive impact of their job performance. Researchers believe that this endeavor will enhance the quality of the existing level of understanding regarding knowledge of HRM and employee job performance in different ways, i.e., methodology, quantitative analysis and new results. Moreover, the results of the mediating role of job satisfaction between HR practices and employee job performance on a sample of faculty members of public sector universities are quite unique. This research reconfirms the findings of the previous researchers. The results of this study also document that universities should have proper HR practices system because they are productive in many ways. In a nutshell, the researchers conclude from the findings of their current research that HR practices enhance the extent of employee job performance of faculty members in the target population through job satisfaction.

\section{References}

Abdullah, Z., Ahsan, N., \& Alam, S. S. (2009). The effect of human resource management practices on business performance among private companies in Malaysia. International Journal of Business and Management, 4(6), 65-72.

Abutayeh, B., \& Al-Qatawneh, M. (2012). The effect of human resource management practices on job involvement in selected private companies in Jordan. Canadian Social Science, 8(2), 50-57.

Afsana, J., Afrin, F., \& Tarannum, T. (2016). Effect of training on employee performance: An empirical study on telecommunication industry in Bangladesh. Journal of Business and Technology (Dhaka), 10(2), 67-80.

Ahmad, S., \& Shahzad, K. (2011). HRM and employee performance: A case of university teachers of Azad Jammu and Kashmir (AJK) in Pakistan. African journal of business management, 5(13), 5249-5253.

Ahmed, I., \& Yohanna, Y. (2014). Training and development as a tool for enhancing employee's productivity: A case study of Ashaka cement company, Nigeria Plc. IOSR Journal of Business and Management, 16(5), 17-26.

Akinbode, G. A. (2011). Demographic and dispositional characteristics as predictors of organizational citizenship behaviour. IFE PsychologIA: An International Journal, 19(1), 375-404.

Al-Mzary, M. M. M., Al-rifai, A. D. A., \& Al-Momany, M. O. E. (2015). training and its impact on the performance of employees at Jordanian universities from the perspective of employees: The case of Yarmouk University. Journal of Education and Practice, 6(32), 128-140.

Ali, Q., \& Jadoon, M. Z. I. (2012). Towards an indigenous perspective on HRM: A study of textile industry of Pakistan. International Journal of Management and Organizational Studies, 1(2), 44-52.

Alsabbah, M. Y., \& Ibrahim, H. (2014). HRM practices and employee competence: A general system perspective. International Journal of Business, Economics and Law, 4(1), 11-17.

Amin, M., Khairuzzaman Wan Ismail, W., Zaleha Abdul Rasid, S., \& Daverson Andrew Selemani, R. (2014). The impact of human resource management practices on performance: Evidence from a Public University. The TQM Journal, 26(2), 125142.

Bashir, S., \& Khattak, H. R. (2008). Impact of selected HR practices on perceived employee performance, a study of Public Sector Employees in Pakistan. European Journal of Social Sciences, 5(4), 243-252.

Bilal, J., \& Naintara, S. R. (2011). Impact of compensation, performance evaluation and promotion practices on government employees' performance vs private employees. Interdisciplinary Journal of Contemporary Research in Business, 3(8), 907913.

Byrne, B. M. (2001). Structural equation modeling with AMOS, EQS, and LISREL: Comparative approaches to testing for the factorial validity of a measuring instrument. International Journal of Testing, 1(1), 55-86.

Michael, B. P. (1964). Exchange and power in social life. New Jersey, United States: Transaction Publishers.

Brown, M., \& Heywood, J. S. (2005). Performance appraisal systems: determinants and change. British Journal of Industrial Relations, 43(4), 659-679. 
Byremo, C. S. (2015). Human resource management and organisational performance: Does HRM lead to better organisational performance? (Unpublished master's thesis). University of Oslo, Oslo.

Casper, W. J., \& Harris, C. M. (2008). Work-life benefits and organizational attachment: Self-interest utility and signaling theory models. Journal of Vocational Behavior, 72(1), 95-109.

Connelly, B. L., Certo, S. T., Ireland, R. D, \& Reutzel, C. R. (2010). Signaling theory: A review and assessment. Journal of Management, 37(1), 39-67. doi: 10.1177/0149206310388419

Conway, N., \& Briner, R. B. (2005). Understanding psychological contracts at work: A critical evaluation of theory and research. United Kingdom: Oxford University Press.

Dar, A. T., Bashir, M., Ghazanfar, F., \& Abrar, M. (2014). Mediating role of employee motivation in relationship to postselection HRM practices and organizational performance. International Review of Management and Marketing, 4(3), 224238.

Delaney, J. T., \& Huselid, M. A. (1996). The impact of human resource management practices on perceptions of organizational performance. Academy of Management journal, 39(4), 949-969.

Guest, D. E. (1997). Human resource management and performance: A review and research agenda. International journal of human resource management, 8(3), 263-276.

Gürbüz, S. (2009). The effect of high performance HR practices on employees' job satisfaction. Istanbul University Journal of the School of Business, 38(2), 110-123.

Hashim, M., Rafi, S., Kazmi, S. S. A., Ullah, M., \& Kee, D. M. H. (2017). Impact of human resource practices on perceived performance: A study of teaching faculty in private universities of Peshawar, Pakistan. City University Research Journal (Special Issue), 120-129.

Hassan, S. (2016). Impact of HRM practices on employee's performance. International Journal of Academic Research in Accounting, Finance and Management Sciences, 6(1), 15-22.

Huselid, M. A. (1995). The impact of human resource management practices on turnover, productivity, and corporate financial performance. Academy of management journal, 38(3), 635-672.

Khan, A. A., Abbasi, S. O. B. H., Waseem, R. M., Ayaz, M., \& Ijaz, M. (2016). Impact of training and development of employees on employee performance through job satisfaction: A study of telecom sector of Pakistan. Business Management and Strategy, 7(1), 29-46.

Khan, M. I. (2012). The impact of training and motivation on performance of employees. Business Review, 7(2), 84-95.

Khan, M. A. (2010). Effects of human resource management practices on organizational performance-an empirical study of oil and gas industry in Pakistan. European Journal of Economics, Finance and Administrative Sciences, 24(6), 157-174.

Khan, Z., Khan, A. S., \& Khan, I. (2017). Impact of performance appraisal on employee's performance including the moderating role of motivation: A survey of commercial banks in Dera Ismail Khan, Khyber Pakhtunkhwa, Pakistan. Universal journal of industrial and business management, 5(1), 1-9.

Khilji, E. (2002). Modes of convergence and divergence: An integrative view of multinational practices in Pakistan. International Journal of Human Resource Management, 13(2), 232-253.

Locke, E. A. (1976). The nature and causes of job satisfaction. In M. D. Dunnette (Ed.), Handbook of industrial and organisational psychology (pp. 1297-1343) Chicago, IL: Rand-McNally.

Macey, W. H., \& Schneider, B. (2008). The meaning of employee engagement. Industrial and organizational Psychology, $1(1), 3-30$.

Malik, M. E., Nawab, S., Naeem, B., \& Danish, R. Q. (2010). Job satisfaction and organizational commitment of university teachers in public sector of Pakistan. International journal of business and management, 5(6), 17-26.

Mohammad, J. U, Miah, M. A. S., Rahman, M. M., \& Rahaman, M. S. (2017). Mediation role of job satisfaction on HRMoperational performance relationship: A three-way moderation effect by gender. The Journal of Developing Areas, 51(3), $437-452$.

Nadarajah, S., Kadiresan, V., Kumar, R., Kamil, N. N. A., \& Yusoff, Y. M. (2012). The relationship of HR practices and job performance of academicians towards career development in Malaysian Private Higher Institutions. Procedia-Social and Behavioral Sciences, 57, 102-118.

Nzyoka, C. M., \& Orwa, B. H. (2016). The relationship between Total compensation and employee performance in the insurance industry, case of Mayfair insurance company limited. Psychology and Behavioral Sciences, 5(1), 20-36.

Okechukwu, W. (2017). Influence of training and development, employee performance on job satisfaction among the staff. Journal of Technology Management and Business, 4(1), 1-16. 
Pangil, F, \& Othman, S. (2016). Examining the link between HRM practices and employees' performance in Nigerian public sector. Management Science Letters, 6(6), 395-408.

Petros, P. (2014). The effect of human resource practices on employee performance in hospitals: A systematic review. Journal of Alternative Medicine Research, 6(1), 19-26.

Pradhan, R. K, \& Jena, L. K. (2016). Workplace spirituality and employee engagement: A study in Indian service industry. In A. K. Birdie (Ed.), Employees and employers in service organizations: Emerging challenges and opportunities (pp. 223 246). US: Apple Academic Publishers, Taylor and Francis Group.

Pradhan, R. K., Dash, S., \& Jena, L. K. (2017). Do HR practices influence job satisfaction? examining the mediating role of employee engagement in Indian public sector undertakings. Global Business Review, 20(1), 1-14.

Quresh, T. M., Akbar, A., Khan, M. A., Sheikh, R. A., \& Hijazi, S. T. (2010). Do human resource management practices have an impact on financial performance of banks? African Journal of Business Management, 4(7), 1281-1288.

Rana, M. H., \& Malik, M. S. (2017). Impact of human resource (HR) practices on organizational performance: Moderating role of Islamic principles. International Journal of Islamic and Middle Eastern Finance and Management, 10(2), 186-207.

Raza, A. (2017, September 05). With just 4 universities in top 1,000, Pakistan falls in world rankings this year, Dawn. Retrieved from https://www.dawn.com/news/1355788

Rehman, S. (2012). A study of public sector organizations with respect to recruitment, job satisfaction and retention. Global Business and Management Research, 4(1), 76-88

Saleem, I., \& Khurshid, A. (2014). Do human resource practices affect employee performance? Pakistan Business Review, $15(4), 669-688$.

Sardar, S., Rehman, A., Yousaf, U., \& Aijaz, A. (2011). Impact of HR practices on employee engagement in banking sector of Pakistan. Interdisciplinary Journal of Contemporary Research in Business, 2(9), 378-389.

Sattar, T., Ahmad, K., \& Hassan, S. M. (2015). Role of human resource practices in employee performance and job satisfaction with mediating effect of employee engagement. Pakistan Economic and Social Review, 53(1), 81-96.

Schumacker, R. E., \& Lomax, R. G. (2015). A beginner's guide to structural equation modeling, 4th Edition. United Kingdom: Taylor \& Francis.

Shah, S. S. H., Yasmin, R., Waris, S., Jaffari, A. R., Aziz, J., Ejaz, W., \& Fatima, M. (2012). The impact of HR dimensions on organizational performance. African Journal of Business Management, 6(4), 1306-1314.

Shahzad, K., Bashir, S., \& Ramay, M. (2008). Impact of HR practices on perceived performance of university teachers in Pakistan. International review of business research papers, 4(2), 302-315.

Singh, H. (2016). Impact of training on employee performance. International journal of business management and scientific research $18,1-5$.

Singh, N. R, \& Kassa, B. (2016). The impact of human resource management practice on organizational performance-a study on Debre Brehan University. International Journal of Recent Advances in Organizational Behaviour and Decision Sciences, $1(1), 643-662$.

Spence, A.M. (1974). Market signaling: Informational transfer in hiring and related screening processes. United States: Harvard University Press.

Storey, J. (2007). Human resource management: A critical text. United States: Thomson Learning.

Tahir, N., Yousafzai, I. K., Jan, S., \& Hashim, M. (2014). The impact of training and development on employees performance and productivity: A case study of United Bank Limited Peshawar City, KPK, Pakistan. International Journal of Academic Research in Business and Social Sciences, 4(4), 86-98.

Tessema, M. T., \& Soeters, J. L. (2006). Challenges and prospects of HRM in developing countries: Testing the HRMperformance link in the Eritrean civil service. The international journal of human resource management, 17(1), 86-105.

Tsui, A. S., Egan, T. D., \& O'Reilly, C. A. (1992). Being different: Relational demography and organizational attachment. Administrative science quarterly, 549-579.

Vermeeren, B., Steijn, B., Tummers, L., Lankhaar, M., Poerstamper, R. J., \& van Beek, S. (2014). HRM and its effect on employee, organizational and financial outcomes in health care organizations. Human Resources for Health, 12(1), 1-9. doi: $10.1186 / 1478-4491-12-35$

Wright, P. M., \& Kehoe, R. R. (2008). Human resource practices and organizational commitment: A deeper examination. Asia Pacific Journal of Human Resources, 46(1), 6-20.

Zia-ur-Rehman, M., Faisal, H., \& Khan, R. A. (2015). In public sector organizations, how the performance of employees is influenced by the HR practices-analyzing the perspective. Journal of Managerial Sciences, 9(1), 49-68. 